\title{
Smectite in mangrove soils of the State of São Paulo, Brazil
}

\author{
Valdomiro Severino de Souza-Júnior'; Pablo Vidal-Torrado2*; Maria Teresa Garcia- \\ González ; Felipe Macías; Xosé Luis Otero ${ }^{4}$ \\ ${ }^{1}$ UFRPE - Depto. de Agronomia, R. Dom Manoel de Medeiros, s/n. - Dois Irmãos -51171-900 - Recife, PE - \\ Brasil. \\ ${ }^{2}$ USP/ESALQ - Depto. de Ciência do Solo - C.P. 09 - 13418-900 - Piracicaba, SP - Brasil. \\ ${ }^{3}$ CSIC/Instituto de Ciencias Agrárias, Serrano 115 dup - 28006 - Madrid - Spain. \\ ${ }^{4}$ Universidade de Santiago de Compostela - Depto. de Edafologia e Química Agrícola - 15782 - Santiago de \\ Compostela - Spain. \\ *Corresponding author <pablo@esalq.usp.br>
}

\begin{abstract}
Smectitic clay minerals are frequently identified in mangrove soils, but there is little information about their types and origins. Besides their importance in the agronomical and geotechnical areas, smectites play an important environmental role by adsorbing nutrients, organic pollutants and heavy metals. Smectites found in mangrove soils can be of marine or continental detrital origin, or of neoformation origin. Thus, the objective of this study was to identify the types of smectites present in the State of São Paulo mangrove soils (Brazil), and to relate them to their possible origins. Soil samples were taken in five mangroves along the State of Sao Paulo State coast line. The mineral composition of the clay fraction was identified by X-ray Diffractometry (XRD) applying the Greene-Kelly test and by Fourier transform infrared spectroscopy (FTIR). Highlighting the peaks in the $3,560 \mathrm{~cm}^{-1}$ band and in the region near 798 and $820 \mathrm{~cm}^{-1}$, there was a predominance of nontronite in the soil at the Sítio Grande River, Pai Matos Island, Caranguejo Island and Itapanhaú River mangroves, and possibly a lower concentration of ferric montmorillonite in the Escuro River mangrove. Since the continental sediments in these environments are very poor in smectite, the origin of these minerals in the mangrove soils studied is related to sedimentation left by past marine transgressions, to neoformation processes, or yet to a combination of both origins.
\end{abstract}

Key words: Greene-Kelly test, neoformation, nontronite

\section{Esmectitas em solos de mangue no Estado de São Paulo}

RESUMO: Minerais de argila esmectíticos são freqüentemente identificados em solos de manguezais, mas são escassas as informações sobre os tipos encontrados e suas origens. A despeito da importância para a agronomia e geotecnia, as esmectitas desempenham também importante papel no âmbito ambiental, atuando na adsorção de nutrientes, poluentes orgânicos e metais pesados. Esmectitas em solos de manguezais podem ser de origem detrítica, marinha ou continental, e também de neoformação. Assim, este estudo objetivou identificar os tipos de esmectitas presentes em solos de manguezais do Estado de São Paulo e relacioná-los com suas possíveis origens. Para tanto, foram amostrados solos de cinco manguezais distribuídos ao longo do litoral paulista, cuja identificação dos constituintes mineralógicos da fração argila foi realizada por difratometria de raios X (DRX) com aplicação do teste de Greene-Kelly e por espectroscopia no infravermelho com transformada de Fourier (FTIR). Destacando os picos na banda de $3.560 \mathrm{~cm}^{-1}$ e na região próxima a 798 e $820 \mathrm{~cm}^{-1}$, verificou-se o predomínio de nontronita nos solos dos manguezais do Rio Sítio Grande, Ilha de Pai Matos, Ilha do Caranguejo e Rio Itapanhaú e, possivelmente menor participação de montmorilonita férrica no manguezal do Rio Escuro. Como os sedimentos continentais destes ambientes são muito pobres em esmectitas, a origem destes minerais nos solos dos manguezais estudados está relacionada à sedimentação deixada pelas transgressões marinhas pretéritas ou aos processos de neoformação ou, ainda, com uma combinação de ambas origens.

Palavras-chave: teste Greene-Kelly, neoformação, nontronita

\section{Introduction}

Smectites in soils can have a detrital origin when inherited directly from the parent material or an authigenic origin, by the transformation of other phyllosilicates or by neoformation from the precipitation of soil solution elements (Allen and Hajek, 1989). The origins of montmorillonite and beidellite are related to pedogenetic processes, and these minerals are commonly found in the continental environment. On the other hand, the origin of nontronite is normally attributed to marine authigenic processes, being formed from the alteration of volcanic rocks, hydrothermal formation or seafloor halmirolysis (Hillier, 1995).

Since mangrove ecosystems are located in the transition between the continental and marine environments, (Cooper, 2001), the sediment for their formation is supplied by fluvial discharges, tidal currents and wave action (Anthony et al., 2004). Smectitic minerals are frequently found in mangrove mineralogical soil assem- 
blies (Marius et al., 1987; Behling and Costa, 2001, 2004; Prada-Gamero et al., 2004), but there is little information about the types of smectites present in soils under this environment.

Estuarine environments are predominantly deposition areas and important heavy metal and nutrients reservoirs (buffer zones) (Spencer et al., 2003). Therefore, it is important to know their specific composition and their mineralogical soil assembly, in order to understand the physical-chemical processes taking place in these environments.

Smectites in mangrove soils are believed to be of mixed origin, partly continental and partly marine, with the possibility of occurrence of different types of these minerals, such as montmorillonite, beidellite and nontronite. Thus, this study is aimed at identifying the types of smectite present in mangrove soils in the State of Sao Paulo, Brazil, and relating them to their possible origins.

\section{Material and Methods}

The five mangroves studied are located in three regions of the São Paulo State coast line: South Coast, Baixada Santista and North Coast (Figure 1). In the South Coast, soil samples were taken in the Sítio Grande River (SG), Pai Matos Island (PM) and Caranguejo Island (IGUA) mangroves, located in the Cardoso Island, Cananéia Channel and Mar Pequeno right after the Valo Grande base level, respectively; all of these mangroves are part of the Cananéia-Iguape estuarine system. In the Baixada Santista region, soil samples were taken in the Itapanhaú River (ITA) mangrove, in the city of Bertioga; soil samples were also taken in the North Coast, Escuro

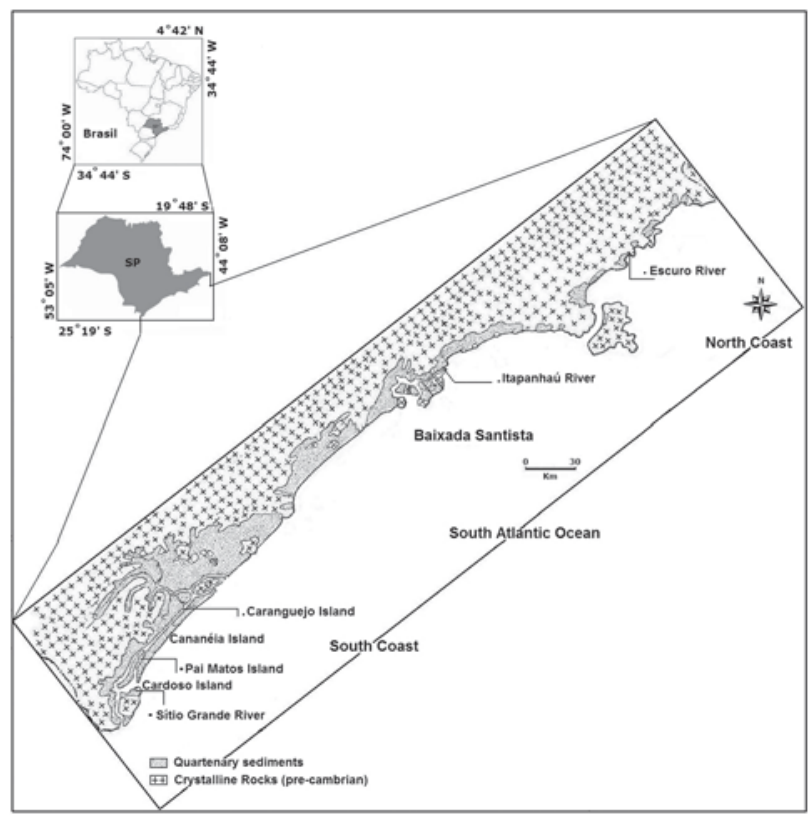

Figure 1 - Geology and geomorphological division of São Paulo State coastal plains, modified from Suguio and Tessler (1992). The location of the sites sampled is shown.
Table 1 - Geographic coordinate of mangroves studied along São Paulo State coast line.

\begin{tabular}{|c|c|c|c|}
\hline Mangrove & Code & Latitude & Longitude \\
\hline \multicolumn{4}{|c|}{ South Coast } \\
\hline Sítio Grande River & SG & $25^{\circ} 04^{\prime} 48^{\prime \prime} \mathrm{S}$ & $47^{\circ} 56^{\prime} 53^{\prime \prime} \mathrm{W}$ \\
\hline Pai Matos Island & PM & $24^{\circ} 59^{\prime} 48^{\prime \prime} \mathrm{S}$ & $47^{\circ} 54^{\prime} 19^{\prime \prime} \mathrm{W}$ \\
\hline Caranguejo Island & IGUA & $24^{\circ} 43^{\prime} 28^{\prime \prime} \mathrm{S}$ & $47^{\circ} 34^{\prime} 00^{\prime \prime} \mathrm{W}$ \\
\hline \multicolumn{4}{|c|}{ Baixada Santista } \\
\hline Itapanhaú River & ITA & $23^{\circ} 51^{\prime} 17^{\prime \prime} \mathrm{S}$ & $46^{\circ} 09^{\prime} 16^{\prime \prime} \mathrm{W}$ \\
\hline \multicolumn{4}{|c|}{ North Coast } \\
\hline Escuro River & $\mathrm{RE}$ & $23^{\circ} 29^{\prime} 20^{\prime \prime} \mathrm{S}$ & $45^{\circ} 09^{\prime} 55^{\prime \prime} \mathrm{W}$ \\
\hline
\end{tabular}

River (RE) mangrove, located south of the city of Ubatuba (Table 1).

The sampling was performed with a flooded soil auger in the $0-20 \mathrm{~cm}$ (surface) and $60-80 \mathrm{~cm}$ (subsurface) layers. The soil samples were submitted to pretreatments, consisting of organic matter elimination with $\mathrm{H}_{2} \mathrm{O}_{2}$ and the washing of soluble salts. The soil samples were dispersed by agitation for 16 hours, using a sodium hydroxide and sodium hexametaphosphate solution as dispersant (Camargo et al., 1986).

The sand fraction was extracted by wet sieving and the clay fraction by sedimentation. The Mg- and K-clay were obtained by saturating the samples with $0.5 \mathrm{~mol}$ $\mathrm{L}^{-1}$ magnesium and potassium chloride at $\mathrm{pH} 7$, respectively. XRD patterns were obtained for the clay fractions of the samples using: i) random powder of the $\mathrm{Mg}$ - and $\mathrm{K}$-saturated clay, and the following oriented aggregates: ii) air dried $\mathrm{Mg}$ - and $\mathrm{K}$-clay ( $\mathrm{Mg}$ and $\mathrm{K})$, iii) $\mathrm{Mg}$-clay ethylene glycol solvated (Mg-E), iv) K-clay heated to $300^{\circ} \mathrm{C}$ for 3 hours (K300), v) K-clay heated to $500^{\circ} \mathrm{C}$ for 3 hours (K500) (Jackson, 1969).

Clay samples were analyzed for the Hofmann and Klemen effect by the application of the Green-Kelly (1953) test. These samples were washed three times with $\mathrm{LiCl} 1 \mathrm{~mol} \mathrm{~L}{ }^{-1}$ and then heated to $270^{\circ} \mathrm{C}$ during $9 \mathrm{~h}$ (Li270). Afterwards these samples were glycerol-solvated (Li270G) and XRD patterns of the Li270 and Li270G samples recorded (Lim and Jackson, 1986). Samples that showed no expansion after solvation with glycerol indicated that the charge was located principally in the octahedral sheet, which is characteristic of the presence of montmorillonite. In contrast, reversible expansion indicated that the charge is located in the tetrahedral sheet and the esmectitic mineral present is beidellite and/or nontronite.

The mineralogical identification was performed by XRD and by Fourier transform infrared spectroscopy (FTIR). X-ray diffraction analyses were performed with a Philips X'Pert diffractometer (graphite monocromated $\mathrm{Cu}-\mathrm{K} \alpha$ radiation). The $\mathrm{X}$-ray tube was operated with a $45 \mathrm{KV}$ tension and a $40 \mathrm{~mA}$ current. The oriented clay samples were analyzed between 3 to $35^{\circ} 2 \theta$ and the nonoriented powder samples between 3 to $70^{\circ} 2 \theta$ in a stepby-step $0.02{ }^{\circ} 2 \mathrm{O} \mathrm{s}^{-1}$ scanning in both cases. 
The infrared analyses were performed with a Shimadzu IR spectrometer using $\mathrm{KBr}$ pressed-discs $(1 \mathrm{mg}$ of sample and $200 \mathrm{mg}$ of potassium bromide) to study the $4,000-400 \mathrm{~cm}^{-1}$ region. A more precise study of the $\mathrm{OH}$ region $\left(4,000-3,000 \mathrm{~cm}^{-1}\right)$ was achieved using fluorolube paste preparations (Russel, 1987).

\section{Results}

\section{X-ray diffractograms}

The mineralogical assembly of the clay fraction of these soils is composed of smectite, mica, kaolinite, gibbsite, goethite, quartz and feldspar (Figures 2 and 3). Mica and kaolinite were present in soils in every sampling location. Mica was identified by the $1.00,0.50$ e 0.334 $\mathrm{nm}$ peaks, while kaolinite was detected by the presence of the 0.712 and $0.356 \mathrm{~nm}$ peaks, which collapsed after heating to $550^{\circ} \mathrm{C}$. Kaolinite presented, in general, intense peaks, with similar levels in all samples. Quartz was identified by the peaks related to interplanar spaces of 0.426 , 0.334 e $0.237 \mathrm{~nm}$; feldspars were identified by peaks in the 0.64 and $0.65 ; 0.403$ to $0.405 ; 0.374$ to 0.378 and 0.317 to $0.322 \mathrm{~nm}$ regions. Gibbsite was observed in all samples, identified by the 0.483 and $0.437 \mathrm{~nm}$ peaks. Goethite was identified only in IGUA by the $0.418 \mathrm{~nm}$ peak (Figure 2).

Smectite was found in all samples, identified by the $1.4 \mathrm{~nm}$ peak, which shifted to $1.68 \mathrm{~nm}$ after ethylene glycol solvation. The PM mangrove stands out from the other mangroves studied, by presenting higher intensity in the peak related to the $1.40 \mathrm{~nm}$ interplanar spacing, with no difference in intensity between the two soil layers. The $60-80 \mathrm{~cm}$ layer in the SG mangrove had the same peak intensity at $1.40 \mathrm{~nm}$ as observed in the PM mangrove, but the peak intensity in the $0-20 \mathrm{~cm}$ layer was lower. The IGUA and ITA mangroves presented the

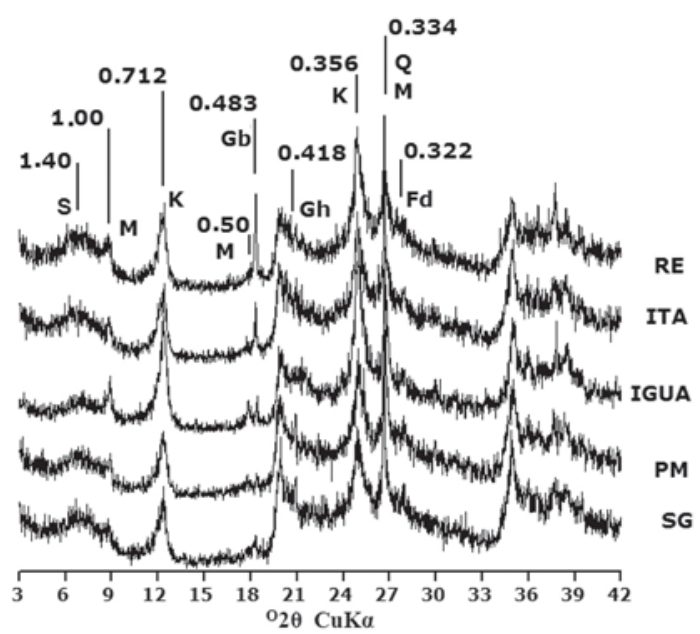

Figure 2 - Clay fraction X-ray diffractograms performed on non-oriented powder samples of the surface layer in the Sítio Grande River (SG), Pai Matos Island (PM), Caranguejo Island (IGUA), Itapanhaú River (ITA) and Escuro River (RE) mangroves. S (smectite), M (mica), K (kaolinite), Gb (gibbsite), Gh (goethite) $\mathrm{Q}$ (quartz), Fd (feldspar). lowest peak intensities at $1.40 \mathrm{~nm}$, mainly in the $60-80$ $\mathrm{cm}$ layer. The peak intensity at $1.40 \mathrm{~nm}$ in the $0-20 \mathrm{~cm}$ layer of the RE mangrove was similar to the SG mangrove, and just as in IGUA and ITA mangroves, the 60$80 \mathrm{~cm}$ layer had a lower intensity in this peak than the surface layer (Figure 3).

The diffractograms of the Li saturated clay samples (Li270 e Li270G) are presented in figure 4. The interlayer expansion of the minerals present in the in SG, PM, IGUA and ITA samples after glycerol solvation suggest that the charges in the smectites of these soils are located in the tetrahedral layer, indicating the presence of beidellite or nontronite smectites. The expansion mentioned above was very tenuous in the RE mangrove sample, which could indicate a smectitic mineral with predominance of charges in the octahedral layer, such as montmorillonite, as pointed by Lim and Jackson (1986).

\section{Fourier transform infrared spectroscopy}

The FTIR spectra obtained (Figures $5 \mathrm{a}, \mathrm{b}$ ) were used to distinguish nontronite from beidellite. The presence of peaks in the $3,560 \mathrm{~cm}^{-1}$ band and in the region around 798 and $820 \mathrm{~cm}^{-1}$ indicates the presence of nontronite in the samples analyzed, since beidellite has peaks in the 920 and 3,660 to 3,630 $\mathrm{cm}^{-1}$ bands (Borchardt, 1989). These results are in agreement with those presented by Kock et al. (1995). Nevertheless, the peak intensity in the band close to $820 \mathrm{~cm}^{-1}$ is higher in the SG, PM and IGUA mangroves, slightly lower in ITA and very low in RE. The low intensity in RE supports the XRD data, which reveals small interlayer expansion after $\mathrm{Li}$ treatment, indicating that this mineral could be a ferric montmorilonite instead of a nontronite (Köster et al., 1999).

The $3,560 \mathrm{~cm}^{-1}$ band peak corresponds to the $\mathrm{AlFeOH}$ bonds stretching vibration, and the 780 to 820 $\mathrm{cm}^{-1}$ bands correspond to the vibrations due to the $\mathrm{FeFeOH}$ bonds deformation vibration (Frost and Kloprogge, 2000). The IR data corroborate the XRD results, confirming the presence of gibbsite in all samples (bands at 3,618, 3,525, 3,391 and 3,375 $\mathrm{cm}^{-1}$ ). Furthermore, the bands at $3,695,3,666,3,653,3,620$ and 912 indicated the presence of kaolinite (Russel, 1987).

\section{Discussion}

The presented results reveal a generalized presence of nontronite in the South Coast and Baixada Santista mangroves, but there is some uncertainty about the RE mangrove in the North Coast. The XRD and FTIR data for this mangrove indicate the presence of ferric montmorillonite.

The soils in the river basins with drainage to the studied coastal plains do not usually have smectite in their mineralogical composition (Sakai and Lepsch, 1984; Rossi, 1999; Furian et al., 2002; Ishida, 2005; Clemente and Azevedo, 2007). Therefore, the nontronite present in the soils studied was either inherited from continental platform marine sediments, is an authigenic mineral, or a combination of both. 

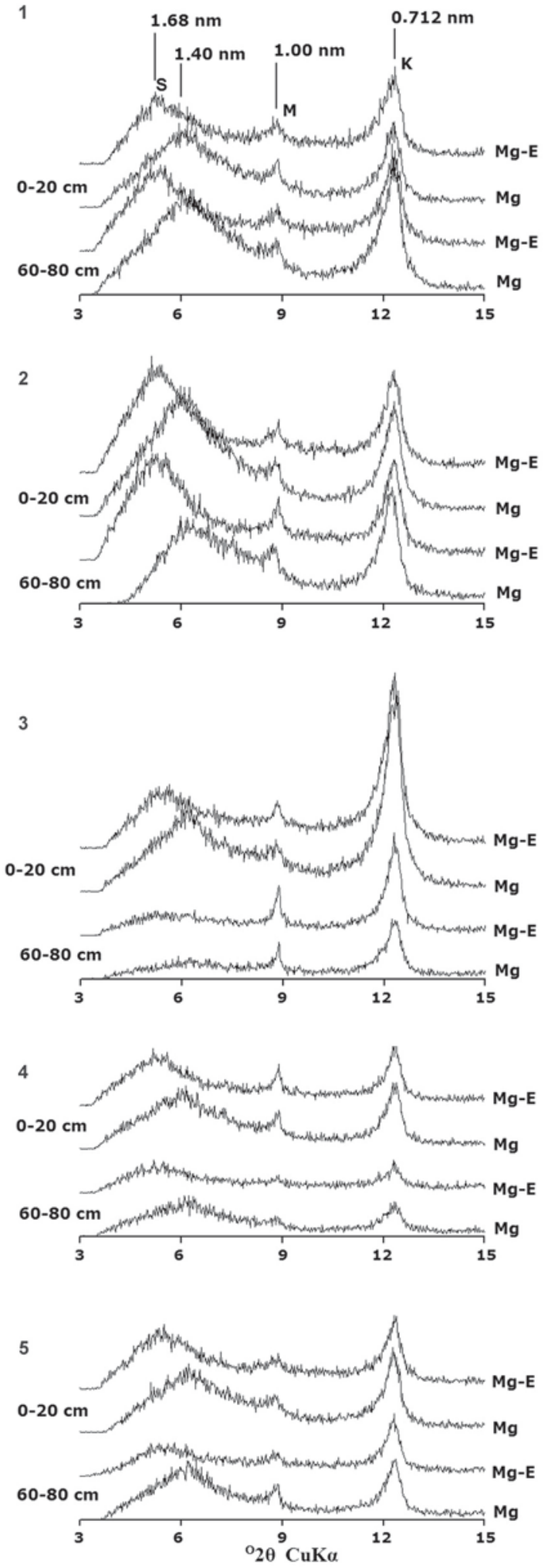

Figure 3 - Clay fraction X-ray diffractograms ( $\mathrm{Mg}$ and $\mathrm{Mg}$ ethylene glycol) of the surface and subsurface layers in the Sítio Grande River (1), Pai Matos Island (2), Caranguejo Island (3), Itapanhaú River (4) and Escuro River (5) mangroves. S (smectite), M (mica) and $\mathrm{K}$ (kaolinite).

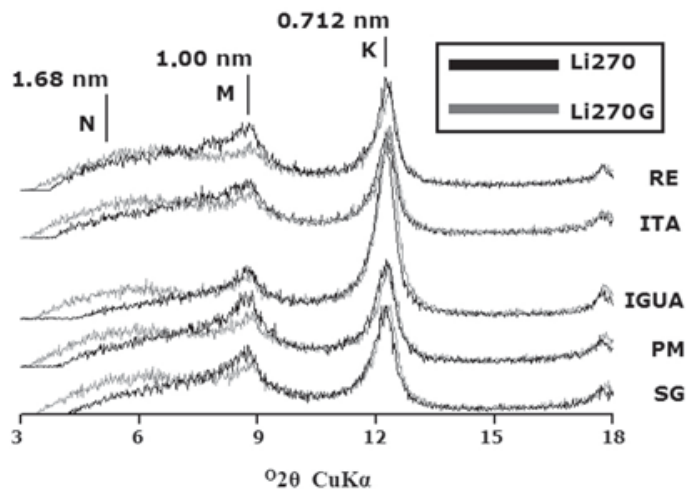

Figure 4 - Clay fraction X-ray diffractograms of the surface layer in the Sítio Grande River (SG), Pai Matos Island (PM), Caranguejo Island (IGUA), Itapanhaú River (ITA) and Escuro River (RE) mangroves, demonstrating the Greene-Kelly test. N (nontronite); M (mica); K (kaolinite). Li 270 (clay fraction oriented aggregates treated with $\mathrm{Li}$ ) e Li270G (clay fraction oriented aggregates treated with $\mathrm{Li}$ and solvated in glycerol).

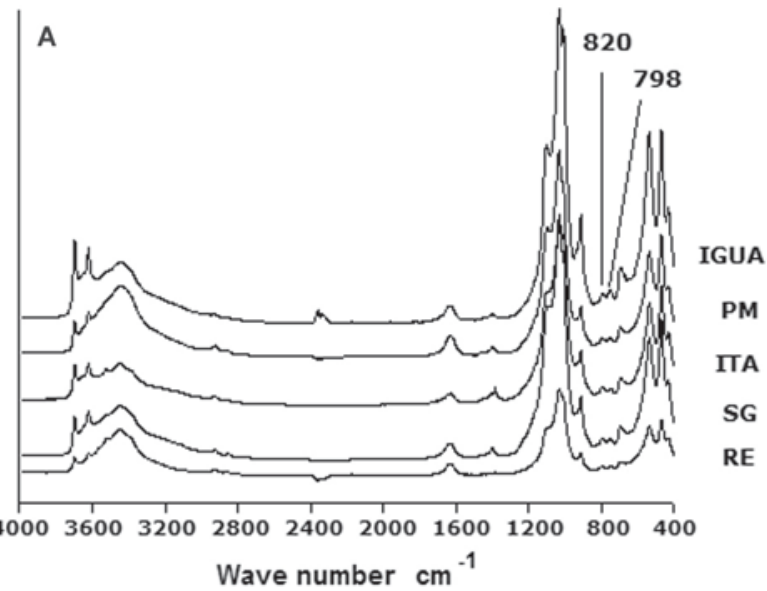

B

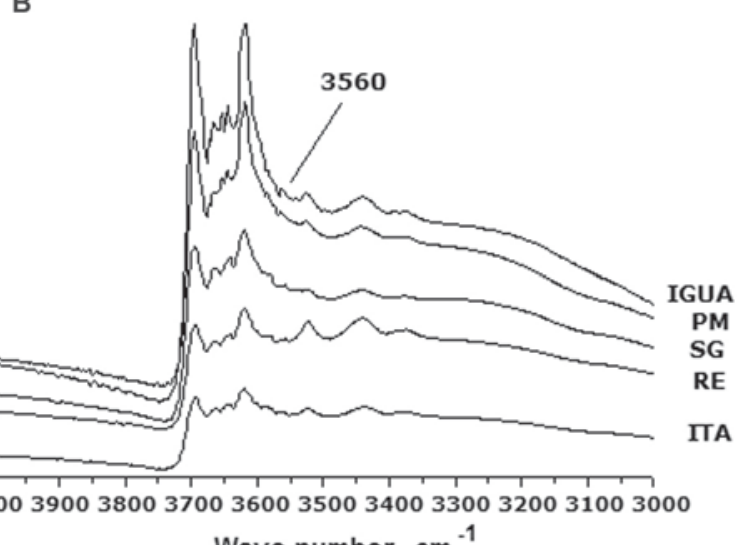

Wave number $\mathrm{cm}^{-1}$

Figure 5 - Fourier transform infrared (FTIR) spectra obtained in the clay fraction of soils sampled in the Sítio Grande River (SG), Pai Matos Island (PM), Caranguejo Island (IGUA), Itapanhaú River (ITA) and Escuro River (RE) mangroves. A) Spectra obtained in BrK dics preparation; B) Spectra obtained in florolube paste preparation. 
When formed in a marine environment, nontronite is originated from volcanic rock alterations, hydrothermal fluids or by halmirolysis (Hillier, 1995). Montmorillonite can also be formed in this environment (Borchardt, 1989). On the other hand, laboratory synthesis studies have shown that the crystallization of beidellite occurs in temperatures above $150^{\circ} \mathrm{C}$ (Kloprogge et al., 1999). Thus, the seafloor authigenic smectite is apparently related to the neoformation of nontronite or even montmorillonite. The formation of seafloor ferric montmorillonite from the oxidation of pyrite was described in a recent study by Gaudin et al. (2005) as the beginning of glauconitization. The predominance of nontronite or ferric montmorilonite in platform environments, and thus its presence in estuary soils would be expected, since the mineralogical assembly of these environments can be formed from both marine and continental sources (Chamley, 1989).

Nontronite authigenesis in mangrove soils and surface sediments can be possible according to the mechanism proposed by Fernandez-Caliani et al. (2004), in which cyclical changes in the redox potential of flooded soils can favor the oxidation of pyrite and subsequent nontronite formation in $\mathrm{Si}, \mathrm{Mg}$ and $\mathrm{Al}$ rich environments. Ferreira (2006) and Otero et al. (2006) found similar conditions in the Pai Matos Island soils. The surface layer of these soils under Rhizophora and Avicennia is highly acid and has high $\mathrm{Fe}$ and sulfate concentrations in the interstitial water as a consequence of iron sulfide (pyrite, and metastable sulfides: $\mathrm{FeS}, \mathrm{Fe}_{3} \mathrm{~S}_{4}$ ) oxidation. Velde and Church (1999) also observed the rapid transformation of illite into smectite in marsh soils, but did not identity the type of smectite formed. It is possible to consider the occurrence of a similar formation in mangrove soils, since these are geomorphologically and geochemically analogous environments. Michalopoulos and Aller (2004) described the rapid formation of authigenic silicates in sediments at the Amazon River base level.

The strong reducing conditions in deeper soil layers lead to a high sulfate-reducing activity, with $\mathrm{H}_{2} \mathrm{~S}$ formation and intense $\mathrm{Fe}$ oxyhydroxide pyritizaton (Ferreira, 2006; Otero et al., 2006). These geochemical conditions can contribute to the instability of nontronite. Thus, is the absence or under low concentration of $\mathrm{Fe}$ oxyhydroxides, the $\mathrm{Fe}$ and sulfate reducing bacteria can promote the partial biological reduction of the $\mathrm{Fe}^{3+}$ present in the nontronite octahedral layer (Kostka et al., 1996, 1999; $\mathrm{Li}$ et al., 2004). This process can lead to alterations in the crystallinity and in the physical-chemical properties of this mineral (Kostka et al., 1999; Li et al., 2004), which could explain the decrease in peak intensity and the increase in peak width of the subsurface layer smectites in the IGUA, ITA and RE mangroves.

\section{Acknowledgements}

This study was partly financed by the CAPES; and FAPESP (Brazil); Dirección General de Universidades del Ministerio de Educación y Ciencia (Spain). The au- thors wish to thank the Instituto de Ciencias Agrarias/ CSIC. Many thanks are due to Dorival Grisotto and Humberto (fieldwork); María Santiso and Beatriz González (for laboratory assistance).

\section{References}

Allen, B.L.; Hajek, B.F. 1989. Mineral occurrence in soil environments. p.199-278 .In: Dixon, J.B.; Weed, S.B. Minerals in soil environments. 2ed. Soil Science Society of America [SSSA], Madison, WI, USA.

Anthony, E.J. 2004. Sediment dynamics and morphological stability of estuarine mangrove swamps in Sherbro Bay, West Africa. Marine Geology 208: 207-224.

Behling, H.; Costa, M.L. 2001. Holocene vegetacional and coastal environmental changes from the Lago Crispin Record in northeastern Pará State, eastern Amazonia. Review of Palaeobotany and Palynology 114: 145-155.

Behling, H.; Costa, M.L. 2004. Mineralogy, geochemistry, and palynology of modern and late Tertiary mangrove deposits in the Barreiras Formation of Mosqueiro Island, northeastern Pará state, eastern Amazonia. Journal of South American Earth Sciences 17: 285-295.

Borchardt, G. 1989. Smectites. p.675-727. In: Dixon, J.B.; Weed, S.B. Minerals in soil environments. 2ed. Soil Science Society of America [SSSA], Madison, WI, USA.

Camargo, O.A.; Moniz, A.C.; Jorge, J.A.; Valadares, J.M.A.S. 1986. Métodos de Análise Química, Mineralógica e Física de Solos do Instituto Agronômico. Instituto Agronômico de Campinas [IAC], Campinas, SP, Brazil.

Chamley, H. 1989. Clay Sedimentology. Springer, Berlin, Germany.

Clemente, C.A.; Azevedo, A.C. 2007. Mineral weathering in acid saprolites from subtropical, southern Brazil. Scientia Agricola 64: 601-607.

Cooper, J.A.G. 2001. Geomorphological variability among microtidal estuaries from the wave-dominated South African coast. Geomorphology 40: 99-122.

Fernandez-Caliani, J.C.; Crespo, E.; Rodas, M.; Barrenechea, J.F.; Luque, F.J. 2004. Formation of nontronite from oxidative dissolution of pyrite disseminated in precambrian felsic metavolcanics of the southern Iberian massif (Spain). Clays and Clay Minerals 52: 106-114.

Ferreira, T.O. 2006. Processos pedogenéticos e biogeoquímica de 'Fe' e 'S' em solos de manguezais. Dr. Thesis. Universidade de São Paulo, Piracicaba, SP, Brazil. (in Portuguese, with summary in English).

Frost, R.L.; Kloprogge, J.T. 2000. Vibrational spectroscopy of ferruginous smectite and nontronite. Spectrochimica Acta 56: 2177-2189.

Furian, S.; Barbiero, L.; Boulet, R.; Curmi, P.; Grimaldi, M.; Grimaldi, C. 2002. Distribution and dynamics of gibbsite and kaolinite in an oxisol of Serra do Mar, southeastern Brazil. Geoderma 106: 83-100.

Gaudin, A.; Buatier, M.D.; Beaufort, D.; Petit, S.; Grauby, O.; Decarreau, A. 2005. Characterization and origin of Fe3+montmorillonite in deep-water calcareous sediments (Pacific Ocean, Costa Rica Margin). Clays and Clay Minerals 53: 452465.

Greene-Kelly, R. 1953. The identification of montmorilonitoids in clays. European Journal of Soil Science 4: 233-237.

Hillier, S. 1995. Erosion, Sedimentation and Sedimentary Origin of Clays. p.162-219. In: Velde, B., ed. Origin and mineralogy of clays "Clays and the Environment". Springer, Berlin, Germany.

Ishida, D.A. 2005. Estudo macro e micromorfológico de seqüência de solos em microbacia hidrográfica no núcleo Cunha-Indaiá no Parque Estadual da Serra do Mar-SP. MSc. Dissertation. Universdade de São Paulo, São Paulo, SP, Brazil. (in Portuguese, with summary in English). 
Jackson, M.L. 1969. Soil Chemical Analysis: Advanced course. University of Wisconsin, Madison, WI, USA.

Kloprogge, J.T.; Komarneni, S.; Amonette, J.E. 1999. Synthesis of smectite clay minerals: A critical review. Clays and Clay Minerals 47: 529-554.

Köster, H.M.; Ehrlicher, U.; Gilg, H.A.; Jordan, R.; Murad, E.; Onnich, K. 1999. Mineralogical and chemical characteristics of five nontronites and Fe-rich smectites. Clays and Clay Minerals 34: 579-599.

Kostka, J.E.; Stucki, J.W.; Nealson, K.H.; Wu, J. 1996. Reduction of structural Fe (III) in smectite by a pure culture of Shewanella putrefaciens strain MR1. Clays and Clay Minerals 44: 522-529.

Kostka, J.E.; Wu, J.; Nealson, K.H.; Stucki, J.W. 1999. The impact of structural $\mathrm{Fe}(\mathrm{III})$ reduction by bacteria on the surface chemistry of smectite clay minerals. Geochimica et Cosmochimica Acta 63: 3705-3713.

Li, Y.L.; Vali, H.; Sears, K.; Yang, J.; Deng, B.; Zhang, C.L. 2004. Iron reduction and alteration of nontronite $\mathrm{NAu}-2$ by a sulfatereducing bacterium. Geochimica et Cosmochimica Acta 68: 3251-3260.

Lim, C.H.; Jackson, M.L. 1986. Expandable phyllosilicate reactions with lithium on heating. Clays and Clay Minerals 34: 346-352.

Marius, C.; Archanjo, D.; Larque, P. 1987. Les sols de mangroves de la baie de Vitoria (Brésil). Cahiers Orstom Série Pédologique 23: 211-216

Michalopoulos, P.; Aller, R.C. 2004. Early diagenesis of biogenic silica in the Amazon delta: Alteration, authigenic clay formation, and storage. Geochimica et Cosmochimica Acta 68: 1061-1085.
Otero, X.L.; Ferrerira, T.O.; Vidal-Torrado, P.; Macias, F. 2006. Spatial variation in pore water geochemistry in a mangrove system (Pai Matos Island, Cananeia-Brazil). Applied Geochemistry 21: 2171-2186.

Prada-Gamero, R.M.; Vidal-Torrado, P.; Ferreira, T.O. 2004. Mineralogia e físico-química dos solos de mangue do rio Iriri no Canal de Bertioga (Santos, SP). Revista Brasileira de Ciência do Solo 28: 233-244.

Rossi, M. 1999. Fatores formadores da paisagem litorânea: A bacia do Guaratuba, São Paulo, Dr. Thesis. Universidade de São Paulo, São Paulo, SP, Brazil. (in Portuguese, with summary in English).

Sakai, E.; Lepsch, I.F. 1984. Levantamento pedológico detalhado da estação experimental de Pariqüera Açú. Instituto Agronômico de Campinas [IAC], Campinas, SP, Brazil. (Boletim Técnico)

Spencer, K.L.; Cundy, A.B.; Croudace, I.W. 2003. Heavy metal distribution and early-diagenesis in salt marsh sediments from the Medway Estuary, Kent, UK. Estuarine Coastal and Shelf Science 57: 43-54.

Suguio, K.; Tessler, M.G. 1992. Depósitos quaternários da planície costeira de Cananéia-Iguape (SP). Publicação Especial Instituto Oceanográfico 9: 1-33.

Velde, B.; Church, T. 1999. Rapid clay transformation in Delaware salt marshes. Applied Geochemistry 14: 559-568.

Received June 26, 2009

Accepted October 19, 2009 